Global Conferences Series:

Social Sciences, Education and Humanities (GCSSSEH), Volume 2, 2019

The $2^{\text {nd }}$ International Conference on Sustainable Development \& Multi-Ethnic Society

DOI: https://doi.org/10.32698/GCS.0168

\title{
Challenges and Obstacle of Outdoor Learning of History Education to enhance the Historical Thinking Skills
}

\author{
Niveetha ${ }^{1}$, Mohd Mahzan Awang ${ }^{2}$, Abdul Razaq Ahmad ${ }^{3}$, Shakila Che Dahalan ${ }^{4}$ \\ ${ }^{1}$ Sekolah Kebangsaan Pandamaran Jaya, MALAYSIA \\ ${ }^{234}$ Faculty of Education UKM, MALAYSIA \\ E-mail: niveethaswary@gmail.com
}

\begin{abstract}
Learning of History is being highlighted and need to be implemented among students since they are in primary schools. Based on past surveys and articles, History is mainly being a subject which rarely focused by students due to more facts to be remembered and known as a boring subject. For a better upgrade in education system, History subject can be taught based on Outdoor Learning activities which could enhance the historical thinking skills among the students. The purpose of this paper is to get to know the challenges and obstacles of Outdoor Learning of History Education to improves the Historical Thinking Skills, have fun and enjoyable learning of History Education among the students, encourage the students to study Historical Education, improve and level up the understanding of the students on Historical Thinking Skills based on Outdoor Learning in History Education and to enhance the development of self-learning in Historical Education. This paper discussed about the introduction, problem statement, importance of implementing the Outdoor Learning of History Education, discussions and conclusions. This paper provides further understanding of the issues and the ways to overcome the obstacles of Outdoor Learning of History Education to mainly enhance the Historical Thinking Skills. We aim to highlight where research has produced some ideas on overcoming the challenges and obstacles that can help to implement the Outdoor Learning in History Education so that it could enhance the Historical Thinking Skills.
\end{abstract}

Keywords: challenges, obstacle, outdoor learning, history education, historical thinking skills

\section{Introduction}

Outdoor Learning is the process of learning which took place in the outdoor of the environment which gave an exposure to the students about the topic they are studying. According to Priest (2012), Outdoor Education is the connection between the subject and how it related to the human and natural resources. Besides that, Outdoor Education is also known as a worldwide education phenomenon which took place to cultivate people in any interesting activities to create a wellbeing person to enhance the future community and environment. Moreover, Outdoor Education that enhancing the learning can expose the students to the future and 
understand the environment well so that it could be the best experience for them to gain knowledge. It can be said that Outdoor Education is the learning that can educate the students to learn something throughout the activities that carried out to enhance the input of knowledge.

Historical Thinking Skills is the way of studying and analyzing the past by having the primary and secondary sources as an important element. These elements are much important in History education to construct a strong basic knowledge of Historical Thinking Skills. As we know, the most common Historical Thinking Skills that have been always being concerned are the important history content such as name, dates, place, incidents, and the person involved. These are the main elements in the Historical Thinking's that make a student to interpret and well conducting the data that they collect to clarify the validity of an incident. Besides that, these elements will always enhance the way and process of collecting and gather the data of a needed topic from different sources. Basically, all the gathered information will be well analyzed by the historian to identify the true concept and the actual meaning of it. In such way, a well-planned past event can be compared and clarified to gain the most important information. It is because Outdoor activities are more likely to view any incident in a visual aspect by using visual materials such as art, maps, and cartoons. Outdoor activities are more on experiencing the content of a textbook by facing the incidents in their lifetime rather than sitting and reading it. As we know, the process of a Historical Thinking Skills based on the discussion, it is more related to the critical thinking skills in human being to enhance their daily lifestyle.

According to Levstik \& Barton (2010), it is proven that Historical Thinking Skills is much needed to cultivate the future learners to become a responsible citizen to create and enhance the democracy of the country. It is the main reason for History subject is being taught in most of the countries. According to Seixas (2015), Historical Thinking Skills is also identified as a way of active thinking which took place basically on the context of any historical incidents. Besides that, it is the starting point of any incident happened so that it could enhance the active learning of the topic studied. In such case, the learnt topic will be highly improving the cognitively process of an individual. However, Historical Thinking Skills should be carried out based on the understanding of the outcome of any learning topics to make sure the whole topic is being conquered strongly by the students. For sure it will be helping the students to truly involve in the learning throughout the end. Besides that, the students will be more active and ready to explore the content of the topic due to the manipulation of the Historical Thinking Skills. In addition, few studies do encourage the implementation of the Historical Thinking Skills to be carried out among the students to make them used to a healthy studying of History subject.

It is very important to make sure that the Historical Thinking Skills to be carried out among the students by conducting the Outdoor Learning. There are many categories of the Outdoor Learning process to be carried out with the students in History subject. Firstly, Outdoor Learning can be conducted outside of the classroom based on the relevant topic which planned by the teacher. This type of learning will make the students to be more concern and focused on their teacher to get to know the input that their teacher is going to give. This is the best way of enhancing the Historical Thinking Skills among the students through the Outdoor Learning. Secondly, there do have some learnings that could be conducted at the relevant places which are located nearby the school that are suitable and mainly related to the topics. This is the way to introduce the students about the History places in our country and its function on those days. These types of learning will surely encourage the students on relating it together with Historical Thinking in order to get to know and explore more about the place. They could find that studying History is actually interesting and fun to deal with.

Moreover, students will be more confident to hire and explore for the knowledge of the visited place to get tom know more about it so that they can experiencing the reality by themselves. Third type of the Outdoor Learning is the one which carried out or conducted to the places those far away from the school which could make the students to explore more about the topic studied. This can be classified as the trips to Historical places to get to know about the incident happened at the specific place which finally identified as a historical place. These types of Outdoor Learnings are more likely to make the students to feel the trips eventually it will make them to experience the feel of those Historical days and the incident took place over there. It will make the students to study History in an interesting way and involve in the trips so that it could help the students to learn more from the visited place. So, it can be concluded that outdoor learning can be conducted anywhere and anytime at suitable places. The purpose of the Outdoor Learning is to enhance the Historical Thinking Skills to be fully implemented among the students.

\section{Problem Statement}

According to Levin (2016), recently fake news spreading so quickly and becoming viral among the community. The fake news misleading the validity in the real world. Stanford History Education Group (2016), has conducted a survey on this issue and find out the information or data is much more 
important to be identified if it's true. Whereby, it can be said that elements in Historical Thinking are being neglected. It is because most of the information from the internet are unable to reason by young people. Therefore, one of the reasons of this paper is to clear the invalidity of information shared that is being trusted by the community without finding its truth. Moreover, subjects like History are highly being highlighted as having the different perception of information and opinions based on previously.

According to the research from Stanford History Education Group, the logical thinking of spreading true information to emphasize the important of reasoning to determine certainty. Moreover, the Learning history is ideal to educate young generation how to search and evaluate online information. Historical Thinking Skills cultivate the habit of rational thinking before any information is being judged. Besides that, fake news can be neglected in many ways. Mainly, to find out the truth in each event occurred historical content has to be processed, managed and be formulated by historical arguments.

It is understood widely that history classes will make students to become bore and lose concentration or focus in classroom. This is why the traditional way of teaching History subject, will limit the foster thinking skills among students. It also happens because history teachers are tasked to cover broad areas of content and controlling student's behavior. So, it is proven that the lacking of Historical Thinking Skills leads to the invalidity of the justifiable information.

\section{Importance of Outdoor Learning to Enhance History Thinking Skills}

Outdoor learning is much more important to enhance the Historical Thinking Skills among students. Therefore, children will be fully involved or active in multiple occasion of Historical Thinking in hands on history spaces. According to Peter Seixas' $(2007 ; 2015)$, there are six Historical Thinking concepts and almost all of the young generation observed in hands on history spaces exemplify evidence of at least one Historical Thinking concept.

As we know, there are 6 main historical thinking skills that need to be implemented in order to further improvise the students thinking ability in history education. The main 6 Historical Thinking Skills are primary sources, historical perspectives, continuity and change, historical significance, the moral dimension of historical perspectives and causes and consequences of any historical incidents. Each and every element in this historical thinking skills are mainly to clarify the incident's validity. Therefore, any incident should be clarified according to each element in historical thinking skills to make sure the truth to be spread out. So, the step to enhance this should be carried out since in primary school. Moreover, History is playing an important role to enhance this skill among the students. As per Von Heyking (2009) statement, students can nourish their skills and think historically if they are given the favorable and suitable power of support. With the ability of Historical Thinking Skills students are able to understand a very complicated issue or concept and able to break down the complex situation into a simpler form. This skill, not only cultivate the habit of critical thinking, also improves the problem-solving skills among students.

Mainly, the most important for students to develop their skills is to get to know their surroundings and the purpose of history is being taught. It is because, in Malaysia, History is being taught from Standard 4 until Standard 6 for primary students. History for Standard 4 is basically taught on all about before the alphabetical are being recognized. It's basically more about the history on student's surroundings such as to get to know the background of themselves, family, school, and Malaysian History. Therefore, it's much more important to cultivate the students to get to know the entire things which is happening in their life. So, in that case, Historical Thinking Skills are playing an effective role to enhance the proper thinking of analyzing the incident occurred, the date and time of the incident, the causes and consequences of the incident, the sources that make the incident to take place and the continuity of it.

Similar to findings in studies by Barton (2009), Von Heyking (2009), and Monte-sano and Reisman (2015), it is defined that the first step for children to actively involved or engaged in Historical Thinking Skills is via the close communication with their family regarding personal and family history. Directly or indirectly children prove the historical thinking by having conversation with adults or parents or elder siblings. Commonly the conversation will visualize or conceptualize family experience or histories in which the historical concept presented by the object, activity, or exhibit was linked to something familiar to the child either a family story or something they may remember from their own life. This is also supported by the fact of Povis and Crowley (2015), where family learning talk playing an important role in implementing the Historical Thinking Skills by relating the experience of family for a deeper knowledge and a better understanding of materials.

In addition, it is also proven that the combination of communication and the hands-on engagement allow or empower children to understand what are they doing. It encourages the children to think out of the box and act 
beyond the concrete object. Moreover, it will stimulate the connection between the initial knowledge and new learning. Therefore, historical thinking is also important to make the strong bonding among all the relations which can help to rebuild a past incident to clarify its data. In such way, the proper way of thinking skills in history is much needed to build students' knowledge. This is what that has been highlighted by most of the surveys and researches. So, it is important for the teachers to implement the historical thinking skills in themselves so that it could be cultivated among their students.

For the current generation, there should be an effective way of enhancing the historical thinking skills among the students. This paper is mainly encouraging the historical thinking skills to be implemented based on Outdoor Learning. As we know, outdoor learning can be carried out to the relevant history places to make a chance for the students themselves to explore the place and collect data based on their observation. These experiences could slowly cultivate and improve their questioning skills to clear their doubts. These are the experiences that could also improves their historical thinking skills. Besides that, outdoor learning can also be a fun and enjoyable experience for the students. Basically, these types of feel will make the students to understand and remember more on what they are seeing or doing. It is because they are experiencing the scenario by themselves which will make them to remember it firmer.

According to the findings of Lozada and Carro (2016), Historical Thinking Skills are strongly improved when children actively utilized historical materials or any incidents directly. It will increase their cognitive level. As a conclusion, Outdoor Learning is the most efficient way to foster and strengthen the Historical Thinking Skills by giving them the reality of the living moments.

\section{Challenges and Obstacles of Outdoor Learning to Enhance History Thinking Skills}

Moving forward to the next generation, we have to identify the possible or the prospective methods, to engage young generation in historical thinking. One of the best methods identified is, outdoor learning. The main motive of this study, is to understand more about the obstacles and challenges of outdoor learning to enhance history skills. First of all, time is being the biggest challenge on conducting the outdoor learning basically in history subject. Normally, any topics that related to the History Education requiring more time to be implemented in the classroom. Therefore, teachers need extra time to conduct outdoor learning which seems to be impossible. This is because understandably, most teachers are occupied with the existing packed schedule and classes.
Also, the big or far scope of historical places such as (Malacca, rural areas, museum and etc.) that need to be visited that causes the insufficient of time.

Secondly, less efficiency of teachers in conducting Outdoor Learning is also one of the challenges identified. Basically, teachers should understand that it's not a matter of more time, just time used in a different way. Teacher's main concern is to find the outdoor learning area, outside of the school day. This can be overcome by organizing a gathering at outdoor to expose the students to the different environment of learning. This could help the student to use to the outdoor learning that furtherly will make them feel better to study in a different place.

Besides that, curriculum integration is also being an important fact that being a challenge to enhance the outdoor learning skills in history education. The traditional assumption and mindset of teachers is, outdoor learning is irrelevant to the curriculum and considered as an extra burden and time consuming. It is strongly believed that the schools enhanced learning should not be carried out by a teacher. Teachers initiative to having the Outdoor activities at the outside of the classroom is believed to be decreasing due to the more aspect is been intergrized in the curriculum. This packed curriculum integration leads the teachers feel fine to conclude the lesson just being in the classroom. It is proving that the teachers were less concern that outdoor learnings can provide the better experience when students learn history content on the occurred venue or outside the classroom. At this point, it becomes the less chances for strong base for the historical thinking skills to implemented in students.

The idea of conducting outdoor learning in both venue and content helps students to visualize and understand the syllabus in a more meaningful way. How can we conduct an efficient outdoor learning within school compound? The best way is by planning or provide a stage for an activity such as storytelling about Hang Tuah. Besides that, interesting activity such as explorace to exploit the content of syllabus. It could impress and inspire students to be proactively attach to the flow of the learning process. Recent survey highlights, these ways can widen the scope of learning curve among students. Indirectly, it also become the energy boost for student since they move around to learn new things. Unfortunately, these ways are rarely carried out by schools and teachers, therefore its still being the challenge for these skills are being implemented.

In addition, classroom management can also be classified as an obstacle in encouraging the outdoor learning. It has become a nightmare for teachers to control their students since students mostly lose control and become 
excited in the outdoor venues. In usual scenarios, kids wildly run around the school grounds and teachers become helpless. So, teacher's primary responsibility is to set clear behavior expectations to the students before going out to the outdoors. Teachers will be having hard time to go over the rules again once the group is outside in the teaching area. For example, teachers can use the smallest useful area to conduct an outdoor learning activity. In cases such as observation and description activity, teachers must be smart enough to handle the students by placing them in a small area. In another hand, planning various and fun activities in a smaller site would result in an effective way in outdoor learning. So, it could be concluded that small scale area would keep the circle of the students closely to the teacher and more time is spent in the activity.

It is a common perception of teachers that classes seem to have different characteristics. In this era, continuous improvement is playing an important role for the better education and to create an innovate generation. According to this, an outdoor activity that have been conducted in the previous year need to be modified significantly or even exchange it with a better idea to give a one step ahead to this year's students. Therefore, teachers must be having a different skill to improves the interest of students in an outdoor learning. Teachers must be able to modify the indoor activity to the outdoor so that it can boost up the student's focus on the subject that being taught. Besides that, early planning of having outdoor classes will merely help the students to fully involve in the learning process and it can be conducted within the expected time. So, the challenges could be cleared easily if all the responsible individual is playing the role to improves the better level of Historical Thinking Skills among the student in History subject.

\section{Conclusion}

As a conclusion, outdoor learning is a best thearapy to educating the students to involve deeply in the Historical Thinking Skills. These skills are need to be implemented since from the primary school whereby, it's a best time for them to make it as a practice to relate it with their daily routine. Historical Thinking Skills which is being enhanced among the students through the Outdoor Learning is the best experience for them to remember what is being taught and to act rationally according to that. It is important for the students to realise that learning can occur anywhere at any time, but its depend on how eager they are to focus and grab the learning efficiently. Moreover, students need to be actively involved in the outdoor learnings because of its unique opportunity to help students to experience the real feel of being at a historical place.
Outdoor learnings will surely develop the student's way of understanding of an historical issue on identifying the truth so that the validity of the issue is being clarified. Besides that, Historical Thinking Skills are more likely to be inserted among students to improves their ability on remember, understand and analyze the fact accordingly to the aspects highlighted in it. In addition, it will be helping the students to firmer their way of communication to increase their level of understanding based on their capability. In such way, the students must be the active participants in the classroom or in the outdoor activities. It is because they are more used to be moving around during their outdoor activity which make them to be more energetic throughout the lesson.

So, it can be concluded that Outdoor Learning are such an amazing way of conducting lessons to enrich the students's ability on encouraging the Historical Thinking Skills. The more the Outdoor Learnings are carried out, the stronger the knowledge that could be gained based on Historical Thinking Skills.

\section{Acknowledgements}

This paper has been developed by a group of researchers from The National University of Malaysia.

\section{References}

[1] Abdullah, Siti Hawa. 2015. Pemikiran Sejarah Dalam Kalangan Sejarawan Novis atau Bakal Guru. Seminar Kebangsaan Majlis Dekan-Dekan Pendidikan Universiti Awam Malaysia.

[2] Allison, pete, David Carr, George Meldrum. 2012: Potential for excellence: Interdisciplinary learning outdoors as a moral enterprise. Curriculum Journal 23, no. 1 43-58.

[3] Arbaa, Rohani, Hazri Jamil \& Nordin Abd Razak. 2010. Hubungan guru-pelajar dan kaitannya dengan komitmen belajar pelajar: Adalah guru berkualiti menghasilkan perbezaan pembelajaran antara jantina pelajar. Jurnal Pendidikan Malaysia 35, no. 2: 61-69.

[4] Bain, Robert B. 2009. Into the breach: Using research and theory to shape history instruction. Journal of education 189, no. 1-2: 159-167

[5] Beyer, Barry K. 2009. How to teach thinking skills in socisl studies and history. The social Studies99, no. 5: 196-201.

[6] Clements, Rhonda. 2009. An investigation of the status of outdoor play. Contemporary issues in early childhood 5, no. $1: 68-80$

[7] Craver, Kathleen W. 2009 Using internet primary sources to teach critical thinking skills in history. Greenwood Publishing Group. 
[8] Eng, James Ang Jit. 2014. Pengurusan Bilik Darjah: Strategi-strategi mewujudkan komuniti pembelajaran berkesan. PTS Publication \& Distributors Sdn Bhd.

[9] Ghani, Muhammad Faizal A. Rosnah Ishak. Saedah Siraj Husaina Banu Kenayathulla. 2017. Keberkesanan amalan organisasi pembelajaran di sebuah sekolah cemerlang di Kuala Terengganu, Terengganu: Satu kajian awal. Juku: Jurnal Kurikulum \& Pengajaran Asia Pasifik 2, no.3: 2242.

[10] Humes, Walter. 2013. Curriculum for excellence and interdisciplinary learning. Scottish Educational Review 45, no.1:82-93.

[11] Kaviza. 2018. Pengalaman Emengajar atau Latihan Profesional Guru dalam Mempengaruhi Penerapan Kemahiran Pemikiran Sejarah dalam Mata Pelajaran Sejarah. EDUCATUM Journal of Social Sciences (EJoss) 4, no 1: 40-47.

[12] McLaughlin, Anne Collins, Alicia Ebbitt McGill. 2017. Explicitly teaching critical thinking skills in a history course. Science \& Education 26, no 1-2: 93-105.

[13] Muniandy, Punitha, Nagamah Marimuthu, Abdul Rahim Ali, Sivarajan Ponniah, Zahari Zainal, Ravendran Chelliah, Jefriza Jefriza. Kajian lapangan meningkatkan kemahiran pedagogi guru Sejarah: Studi kasus di tapak arkeologi lembah bujang dan sungai batu. HISTORIA Jurnal Program Studi Pendidikan Sejarah 6, no.1: 1-14

[14] Payne, Philip G, Brian Wattchow. 2009. Phenomenological Deconstruction, Slow Pedagogy, and the Corporeal Turn in Wild Environmental/Outdoor Education. Canadian Journal of Environmental Education 14, no 1: 15-32.

[15] Ramakrishnan, Renuka, Norizan Esa, Siti Hawa Abdullah. 2014. Kesan penggunaan sumber sejarah digital terhadap kemahiran pemikiran sejarah: 1664-1686

[16] Reed, Jennifer H, Jeffrey D. Kromrey. 2011. Teaching critical thinking in a community college history course: Empirical evidence from infusing Paul's model. College Student Journal 35: no.2: 201-201.

[17] Wallace, Belle. 2013. Using history to develop thinking skills at Key Stage 2. Routledge.

[18] Wattchow, Brian, Mike Brown. 2011. A pedagogy of place: Outdoor education foa a changing world. Monash University Publishing. 